DOI https://doi.org/10.30525/978-9934-26-007-0-19

\title{
КОНЦЕПЦІЯ ВІДПОВІДНОСТІ ТОВАРУ У ПРАВІ ЄВРОПЕЙСЬКОГО СОЮЗУ У КОНТЕКСТІ АДАПТАЦІЇ ЗАКОНОДАВСТВА УКРАЇНИ
}

\section{Саванець Л. М.}

\section{ВСТУП}

Сучасне договірне право Свропейського Союзу зазнає трансформацій, зумовлених викликами цифрової революції, стандартизації та діджиталізації приватно-правових відносин договірного характеру. Прийняттям 20 травня 2019 р. двох довгоочікуваних законодавчих актів Свропейського Союзу, Директиви 2019/770 Європейського Парламенту та Ради про деякі аспекти договорів поставки цифрового контенту та цифрових послуг, Директиви 2019/771 Свропейського Парламенту та Ради про деякі аспекти договорів купівлі-продажу товарів європейському законодавцеві вдалося гармонізувати значну частину цивільного законодавства у формі регулятивного інструменту за умов формування єдиного цифрового ринку. I хоча необхідність нового законодавчого масиву визначалася Стратегією єдиного цифрового ринку для Європи 2015 р., саме розробка нових Директив, на наш погляд, є результатом тривалого процесу європеїзації договірного права, що розпочався із кінця 80-х - початку 90-х рр. минулого століття. Характерними особливостями Директиви 2019/770 та Директиви 2019/771 виступає закріплення принципово нових положень у сфері купівлі-продажу товарів і постачання цифрового контенту на засаді максимальної гармонізації. Водночас деякі питання у сфері договірних відносин купівлі-продажу товарів, пов'язані із їх практичною реалізацією, зокрема відповідність товару та критерії іiі визначення; інформаційні зобов'язання продавця товару із цифровими елементами стосовно оновлення програмного забезпечення 3 метою підтримання їх у відповідності; презумпція невідповідності товару та тягар іiі доведення; засоби правового захисту прав покупця, порушених у зв'язку із невідповідністю товару, на нашу думку, є дискусійними.

Підписавши Угоду про асоціацію із Європейським Союзом, Свропейським співтовариством 3 атомної енергії та їхніми державами-членами, Україна узяла на себе низку зобов'язань, серед яких забезпечення поступової адаптації законодавства України до acquis Свропейського Союзу. Таким чином, Україна виразила готовність імплементувати у національне законодавство чинні акти інститутів Свропейського Союзу відповідно до визначених в угоді напрямів, у т. ч. й у сфері договірних відносин. 
Варто відзначити і те, що процес імплементації нових Директив, які закріплюють положення про відповідність товару, країнами-членами Європейського Союзу припадає на рекодифікацію вітчизняного цивільного законодавства, що підвищує важливість дослідження цих нормативних актів у контексті адаптації законодавства України.

Зазначене підсилює актуальність здійснення наукового дослідження концепції відповідності товару у європейському праві за умов інтеграції України до єдиного ринку Свропейського Союзу.

\section{1. Генеза становлення концепції відповідності товару}

Виходячи із загальних засад відповідальності за порушення зобов'язання, покупець, який за договором купівлі-продажу придбав невідповідний договору товар, був би вправі вимагати від продавця відшкодування завданих збитків, здебільшого у грошовій формі, однак продавець звільнявся би від такої відповідальності за відсутності його вини. Як справедливо відзначає І. Бичковська, за таких обставин відбувалося б порушення принципу еквівалентного виконання, адже придбаний покупцем за договором купівлі-продажу товар був би нерівнозначний сплаченій за нього та вказаній у договорі грошовій сумі ${ }^{1}$. Саме тому цивільне законодавство закріплює спеціальний вид відповідальності продавця за передання товару неналежної якості, гарантуючи ефективніший захист інтересів покупця порівняно із норами, що визначають загальні засади договірної відповідальності. Особливістю відповідальності продавця за неналежну якість проданого товару $є$ відсутність обов'язку покупця доводити вину продавця у виникненні недоліку товару. За умов звичної ринкової переваги пропозиції над попитом покупець, приймаючи рішення про купівлю товару, перебуває у привілейованому становищі, однак воно втрачається за відсутності очікуваних властивостей придбаного товару, за які сплачена грошова сума. Сплачена грошова сума, розрахована як ціна за належний товар, знаходиться у продавця. Можна говорити про понесення фактичного ризику дефектного товару покупцем. Водночас, беручи за основу класичні цивілістичні конструкції, що грунтуються на обтяженні обов'язком доведення вини боржника особи, яка подає вимогу, покупець був би зобов'язаний довести неналежність виконання договірного зобов'язання. Додаткова складність цього доведення полягала б у відсутності поінформованості покупця у встановленні особи, котра б несла відповідальність за дефектність товару: його продавця чи виробника 2 .

\footnotetext{
${ }^{1}$ Byczkowska I. Odpowiedzialność z tytułu rękojmi za wady rzeczy sprzedanej (wybrane zagadnienia). Państwo i prawo. 2000. Zeszyt 9 (655). S. 64-65.

2 Bańczyk W. Zmiany przesłanek odpowiedzialności sprzedawcy w prawie polskim (od wady rzeczy sprzedanej do jej niezgodności z umową). Acta iuris stetinensis. 2018. № 3 (23). S. 10-11; Lubełska-Sazanów M. Odpowiedziałsność z tytułu rękojmi za wady fizyczne przy sprzedaży zwierząt. Transformacje Prawa Prywatnego. 2015. № 4. S. 25.
} 
В основу концепції понесення негативних юридичних наслідків за невідповідність товару договору купівлі-продажу покладено об'єктивну, абсолютну ${ }^{3}$ відповідальність, незалежну від вини та поінформованості продавця про недолік товару в момент його надання покупцеві ${ }^{4}$. Сдиною підставою цього виду відповідальності виступає передання покупцеві товару, що не відповідає договору. Останнє управомочує покупця на застосування спеціальних засобів правового захисту порушених прав та інтересів, а це, у свою чергу, не позбавляє можливості пред'явлення вимоги про відшкодування завданих збитків ${ }^{5}$. Проте, незважаючи на т. зв. абсолютний характер аналізованої відповідальності, у визначених законом випадках допускається звільнення продавця від іï понесення ${ }^{6}$ (наприклад, форс-мажор, виключна вина особи, якій завдано шкоди, або третьої особи).

Принагідно зауважимо, що модель об'єктивної відповідальності за недоліки проданого товару є симбіозом сформованої у римському едикті курильного едила відповідальності за визначені фізичні недоліки речі та напрацювання класичної юриспруденції щодо встановлення загальної відповідальності про приховані недоліки ${ }^{7}$. Погоджуємося із позицією В. Дайчак, що прообразом критеріїв відповідності товару договору, закладених у законодавстві $\mathrm{CC}$, можна вважати домінуючу у правовій доктрині позицію, за якою річ, що продається або передається в найм, завжди повинна бути неушкодженою (omnimodo integrum praestari debet).

$\mathrm{У}$ двох європейських правових традиціях сформувалися різні підходи до закріплення у національному законодавстві спеціального виду відповідальності продавця за договором купівлі-продажу. У праві держав континентальної правової сім'ї, зокрема німецькому, австрійському, французькому, швейцарському, польському, була встановлена заснована на римському праві концепція недоліку (фактичного та юридичного) проданого

\footnotetext{
${ }^{3}$ Żuławska C. Zabezpieczenie jakości świadczenia. Studia cywilistyczne. 1978. T. 29. S. 48; Rembieliński A. Rękojmia sprzedawcy za wady fizyczne rzeczy. Ogólne warunki umów sprzedaży $i$ dostawy. Komentarz / Rembieliński A., Koprowski J., Jaźwiński A. Warszawa 1979. S. 185.

${ }^{4}$ Frąckowiak J. Uprawnienia z rękojmi za wady fizyczne rzeczy sprzedanej. Przegląd prawa $i$ administracji. 2004. T. LXIV. Rozprawy z prawa handlowego. S. 30-31; Widło J. Rękojmia za wady fizyczne w świetle nowelizacji Kodeksu cywilnego. Monitor Prawniczy. 2015. № 4. S. 177; Podrecka M. Rękojmia za wady prawne rzeczy sprzedanej. Warszawa, 2011. S. 22-24.

5 Byczkowska I. Odpowiedzialność z tytułu rękojmi za wady rzeczy sprzedanej (wybrane zagadnienia). Państwo i prawo. 2000. Zeszyt 9 (655). S. 65; Katner W., Pisuliński J. Sprzedaż (w:) System prawa prywatnego. Prawo zobowiązań - część szczegółowa / red. J. Rajski. T. 7. Warszawa : C.H. Beck, 2018. S. 143.

${ }^{6}$ Podrecka M. Rękojmia za wady prawne rzeczy sprzedanej. Warszawa, 2011. S. 23-27; Lubełska-Sazanów M. Odpowiedziałsność z tytułu rękojmi za wady fizyczne przy sprzedaży zwierząt. Transformacje Prawa Prywatnego. 2015. № 4. S. 26.

${ }^{7}$ Zimmermann R. The law of obligations. Roman foundations of the civilian tradition. Oxford, 1996. P. $311,320$.

${ }^{8}$ Dajczak W. Znaczenie tradycji prawa rzymskiego dla europejskiej harmonizacji prawa prywatnego. Państwo $i$ prawo. 2004. Zeszyt 2 (696). S. 61.
} 
товару ${ }^{9}$. Інше вчення про відповідальність за неналежну якість проданого товару, обгрунтоване необхідністю договірного регулювання, було покладено в основу права держав англосаксонської системи. Саме договір і вказані в ньому в рамках принципу свободи договору положення повинні забезпечувати захист прав та інтересів покупця від можливого набуття товару неналежної якості. Лише подальший розвиток прецедентного права в англосаксонській системі призвів до закріплення у Законі Великої Британії про продаж товарів 1893 p. (Sale of Goods Act 1893) концепції відповідності товару договору ${ }^{10}$. Особливістю права держав системи common law $\epsilon$ те, що, не визнаючи позитивні недоліки товару, воно брало за основу ідею т. зв. «відсутності недоліку» товару ${ }^{11}$. Так, норми Єдиного комерційного кодексу США (Uniform Commercial Code) регулюють відповідальність продавця на підставі законної гарантії (implied warranty) за «придатність для торгівлі» (merchantability) товару, під якою розуміється відсутність недоліків товару та його здатність до застосування з метою, з якою товар зазвичай використовується. Більш того, презюмується, що, якщо продавцю було відомо про спеціальне призначення відчужуваного товару, а покупець розраховував на його професійні знання, то зміст поняття «придатність для торгівлі» охоплює також і його здатність для використання зі спеціальною метою ${ }^{12}$.

Враховуючи значні відмінності практичної реалізації норм про недолік проданого товару у державах континентальної правової традиції, що унеможливлювали узгодження спільного європейського регулювання, під впливом англосаксонської доктрини breach of contract ${ }^{13}$ і $з$ метою гармонізації

\footnotetext{
${ }^{9}$ Longchamps de Berier F. Skargi edylów kurulnych a dyrektywa 1999/44/EC Parlamentu Europejskiego i Rady w sprawie określonych aspektów sprzedaży i gwarancji na dobra konsumpcyjne. Studia Iuridica. 2005. T. XLIV. S. 430-431; Żuławska C. Uwagi o „europeizacji” prawa umów. Kwartalnik Prawa Prywatnego. 2001. № 2. S. 236-237; Bańczyk W. Zmiany przesłanek odpowiedzialności sprzedawcy w prawie polskim (od wady rzeczy sprzedanej do jej niezgodności z umową). Acta iuris stetinensis. 2018. № 3 (23). S. 8.

${ }^{10}$ Mokrysz-Olszyńska A. Dyrektywa 2011/83/UE z dnia 25 października 2011 w sprawie praw konsumentów jako kolejny etap na drodze tworzenia jednolitych reguł konkurencji na unijnym rynku. Internetowy kwartalnik antymonopolowy i regulacyjny. 2013. № 7 (2). S. 80.

Widło J. Rękojmia za wady fizyczne w świetle nowelizacji Kodeksu cywilnego. Monitor Prawniczy. 2015. № 4. S. 177.

${ }_{11}$ Koch A. Wadliwość rzeczy sprzedanych w świetle Konwencji ONZ o międzynarodowej sprzedaży towarów. Przegląd Prawa Handlowego. 1998. № 10. S. 11.

${ }^{12}$ Habryn-Motawska E. Niezgodność towaru konsumpcyjnego z umową sprzedaży konsumenckiej. Warszawa, 2010. S. 22.

${ }^{13}$ Żuławska C. Uwagi o „europeizacji” prawa umów. Kwartalnik Prawa Prywatnego. 2001. № 2. S. 233.

Bańczyk W. Zmiany przesłanek odpowiedzialności sprzedawcy w prawie polskim (od wady rzeczy sprzedanej do jej niezgodności z umową). Acta iuris stetinensis. 2018. № 3 (23). S. 8.

Mokrysz-Olszyńska A. Dyrektywa 2011/83/UE z dnia 25 października 2011 w sprawie praw konsumentów jako kolejny etap na drodze tworzenia jednolitych reguł konkurencji na unijnym rynku. Internetowy kwartalnik antymonopolowy i regulacyjny. 2013. № 7 (2). S. 80.

Popiołek W. Obowiązki sprzedającego. Komentarz do art. 30. Konwencja Wiedeńska o umowach międzynarodowej sprzedaży towarów. Komentarz / red. M. Pazdana. Kraków, 2001. S. 341, 344.
} 
норм про відповідальність продавця за недоліки проданого товару вперше на рівні законодавства Європейського Союзу (далі - СС) Директива 1999/44/СС про деякі аспекти продажу споживчих товарів і пов'язаних із ними гарантій (далі - Директива 1999/44/СС) закріпила поняття відповідності товару (conformity of goods) договору. Концепція відповідності товару договору була перейнята Директивою 1999/44/СС із Конвенції ООН про договори міжнародної купівлі-продажу товарів 1980 р. (далі - Віденська конвенція 1980 р.). Унікальність Віденської конвенції 1980 р., яка зараз застосовується у 92 державах, полягає у значному впливі не тільки на регулювання відносин у міжнародній торгівлі, а насамперед на національне договірне право ${ }^{14}-$ від китайського договірного права до реформ у «державах із перехідною економікою Східної та Центральної Європи, модернізації зобов'язального права Німеччини, Франції та Іспанії» ${ }^{15}$.

Поняття відповідності товару договору є ширшим за поняття недоліку товару, адже не обмежене самим товаром із недоліком ${ }^{16}$, а й охоплює й обгрунтовані очікування покупця ${ }^{17}$ i відсутність властивостей, про які зазначалося в рекламі, або також помилки монтажу чи введення в експлуатацію товару. ${ }^{18}$ I хоча підставою відповідальності продавця формально залишається недолік проданого товару, з огляду на встановлені критерії відповідності товару договору саме тлумачення договірних умов матиме значення під час розгляду вимог покупців ${ }^{19}$. Водночас поняття відповідності товару договору охоплює також вимоги щодо якості, визначені законодавством, звичаями ділового обороту.

Jagielska M. Komentarz do art. 35 Konwencji ONZ. Konwencja Wiedeńska o umowach międzynarodowej sprzedaży towarów. Komentarz / red. M. Pazdana. Kraków, 2001. S. 384.

Koch A. Wadliwość rzeczy sprzedanych w świetle Konwencji ONZ o międzynarodowej sprzedaży towarów. Przeglad Prawa Handlowego. 1998. № 10. S. 10.

Widło J. Rękojmia za wady fizyczne w świetle nowelizacji Kodeksu cywilnego. Monitor Prawniczy. 2015. № 4. S. 178.

${ }^{14}$ Ferrari F. The CISG and its impact on national legal systems. Sellier, 2008. $489 \mathrm{p}$.

${ }^{15}$ Schulze R. The new shape of European contract law. EuCML. 2015. Vol. 4. Issue 4. P. 139-140.

${ }^{16}$ Krupowicz M. Ocena kierunku zmian w zakresie ochrony konsumenta na gruncie ustawy z dnia 27 lipca 2002 r. o szczególnych warunkach sprzedaży konsumenckiej. Rejent. 2005. № 2. S. 145.

Szczotka J. Sprzedaż konsumencka. Komentarz. Lublin, 2007. s. 46; Żuławska C. Uwagi o „europeizacji” prawa umów. Kwartalnik Prawa Prywatnego. 2001. № 2. S. 236-237.

Sikorska A. Ciężar dowodu w przypadku odstąpienia od umowy sprzedaży przez kupującego z powodu wad rzeczy lub niezgodności towaru z umową. Radca prawny. 2005. № 1. S. 60.

${ }^{17}$ Łętowska E. Prawo umów konsumenckich. Warszawa, 2002. S. 390.

Podrecki P., Zoll F. Odpowiedzialność z tytułu rękojmi i gwarancji w umowach sprzedaży z udziałem konsumentów. Ochrona konsumentów / red. E. Traple, M. du Vall. Cz. 1. Warszawa, 1998. S. 111.

Stefanicki R. Zapewnienia reklamowe jako kryterium oceny zgodności towaru konsumpcyjnego z umową sprzedaży. Kwartalnik Prawa Prywatnego. 2004. Zeszyt 1. S. 171.

Gajek M. Niezgodność z umową jako przesłanka odpowiedzialności sprzedawcy towaru konsumpcyjnego. Monitor Prawniczy. 2003. № 5. S. 210.

${ }^{18}$ Makowska A. Sprzedaż konsumencka w prawie Unii Europejskiej i prawie polskim. Toruń, 2006. S. 49.

${ }^{19}$ Bańczyk W. Zmiany przesłanek odpowiedzialności sprzedawcy $\mathrm{w}$ prawie polskim (od wady rzeczy sprzedanej do jej niezgodności z umową). Acta iuris stetinensis. 2018. № 3 (23). S. 30. 
Концепція відповідності товару (цифрового контенту) відображена й у нових Директивах, що визначають вектор майбутнього розвитку договірного права ЄС, Директиві 2019/770 про деякі аспекти договорів поставки цифрового контенту та цифрових послуг (далі - Директива 2019/770) та Директиві 2019/771 про деякі аспекти договорів купівлі-продажу товарів (далі - Директива 2019/771).

Принагідно зауважимо, що із прийняттям Директиви 2019/771 втрачає чинність Директива 1999/44/СС. Нова Директива 2019/771, як і Директива 1999/44/СС, закріплює два типи гарантії якості проданого товару: законну та договірну (комерційну (торгову)). Законна гарантія проданого товару виступає способом захисту еквівалентності виконання, довіри покупця ${ }^{20}$ до належного виконання зобов'язання продавцем. Особливістю відповідальності на основі цієї гарантії якості товару є існування недоліків товару до моменту його переходу до покупця, так би мовити «всередині речі», а не їх виникнення внаслідок використання товару ${ }^{21}$. В останньому випадку відповідний режим захисту встановлюється договірною гарантією якості товару.

Варто погодитися із позицією, висловленою у літературі, за якою наявний стан правового регулювання відповідальності за невідповідність товару, підстав такої відповідальності, їх інтерпретації та місця в системі загальної відповідальності за порушень зобов'язань залежить від певних історичних традицій, економічних умов, а також правової культури певної держави ${ }^{22}$. Однією із класичних цивілістичних проблем є питання співвідношення режиму відповідальності в межах законної гарантії якості товару та загальних положень про договірну відповідальність. У правовій доктрині це питання остаточно не вирішене. Згідно $з$ домінуючим поглядом існування спеціального режиму відповідальності за невідповідність проданого товару договору не виключає загального режиму договірної відповідальності. Вони не залежать один від одного і регулюються власними правилами, наприклад, стосовно підстав виникнення відповідальності або строків, що ії обмежують. Покупець із метою захисту порушеного права може реалізовувати як спеціальні способи захисту, встановлені режимом відповідальності за невідпо-відність проданого товару договору, так і загальні в межах режиму відповідальності за порушення договірного зобов'язання ${ }^{23}$.

\footnotetext{
${ }^{20}$ Podrecki P., Zoll F. Odpowiedzialność z tytułu rękojmi i gwarancji w umowach sprzedaży z udziałem konsumentów. Ochrona konsumentów / red. E. Traple, M. du Vall. Cz. 1. Warszawa, 1998. S. 118.

${ }^{21}$ Katner W., Pisuliński J. Sprzedaż (w:) System prawa prywatnego. Prawo zobowiązań - część szczegółowa / red. J. Rajski. T. 7. Warszawa : C.H. Beck, 2018. S. 127.

${ }^{22}$ Łętowska E. Prawo umów konsumenckich. Warszawa, 2002. S. 380.

23 Szpunar A. Uwagi w sprawie wykładni art. 568 k.c. Przeglad prawa handlowego. 1997. № 5. S. 4; Łętowska E. Prawo umów konsumenckich. Warszawa, 2002. S. 378; Podrecka M. Rękojmia za wady prawne rzeczy sprzedanej. Warszawa, 2011. S. 117.
} 
Водночас необхідно враховувати, що реалізація вимоги про відшкодування збитків не пов'язана зі здійсненням спеціальних способів захисту, передбачених правилами про відповідальність у межах законної гарантії якості товару, включаючи спеціальні строки. Також покупець, котрий не відмовляється від договору або не вимагає зниження ціни (заміни чи ремонту товару), може звернутися із вимогою про відшкодування шкоди, завданої порушенням зобов'язання ${ }^{24}$.

\section{2. Основні новели законодавства СС у сфері відповідності товару}

У нових Директивах СС, Директиві 2019/771 і Директиві 2019/770 значна увага приділена питанню відповідності як одному із ключових у сучасному договірному праві ${ }^{25}$. Положення Директив покладають на продавця (постачальника) обов'язок передати споживачеві товари або цифровий контент чи надати цифрову послугу, які задовольняють вимоги відповідності (ст. 5 Директиви 2019/771, ст. 6 Директиви 2019/770). Новелою обох Директив виступає чіткий поділ критеріїв відповідності на суб'єктивні й об'єктивні. Варто зазначити, що норми Директиви 1999/44/СС, як і Віденської конвенції 1980 р., не закріплювали поділу критеріїв відповідності товару на об'єктивний i суб'єктивний i регулювали це питання за суб'єктивною ознакою, виходячи із домовленостей сторін як основної підстави визначення відповідності товару. Зазначена концепція грунтувалася на принципі свободи договору, який встановлює можливість сторін вільно визначати предмет договору купівлі-продажу. Аналізуючи положення ст. 99-100 Загальноєвропейського права купівлі-продажу, можна дійти висновку, що вперше об'єктивний критерій відповідності товару визначався саме в ньому. Розробники проекту, на думку Ф. Цолля, відійшли від суб'єктивної концепції невідповідності товару договору, намагаючись «зміцнити» особливості товару, підвищити критерії встановлення відхилень від прийнятого стандарту ${ }^{26}$.

Аналізуючи положення п. b), с) ч. 1, п. b) ч. 2 ст. 8 Директиви 2019/770 і п. с), d) ч. 1, п. а) ч. 3 ст. 7 Директиви 2019/771 про об'єктивні критерії відповідності товару, простежуємо використання європейським законодавцем оціночного юридичного поняття «обгрунтовані очікування»

\footnotetext{
${ }^{24}$ Strugała R. Odpowiedzialność odszkodowawcza sprzedawcy związana z realizacją uprawnień z tytułu rękojmi a ogólne zasady kontraktowej odpowiedzialności odszkodowawczej. Transformacje Prawa Prywatnego. 2015. № 4. S. 94.

${ }^{25}$ Schulze R. Supply of digital content - a new challenge for european contract law. European contract law and the digital single market - the implications of the digital revolution / ed. by Franceschi A.D. Intersentia 2016. P. 127-144.

${ }^{26}$ Zoll F. Problem negatywnego uzgodnienia cech rzeczy sprzedanej - w oczekiwaniu na wspólne europejskie prawo sprzedaży. Transformacje prawa prywatnego. 2012. № 2. S. 168, 171.
} 
(reasonably expect). Принагідно зауважимо, що концепція «обгрунтованих очікувань споживача» містилася у Директиві 1999/44/СС (п. d) ч. 2 ст. 2) та була запозичена 3 англійського законодавства ${ }^{27}$. Критерієм визначення «обгрунтованого очікування» виступають не суб' єктивні сподівання певного споживача, а те, що підлягає об'єктивному встановленню, враховуючи предмет договору, обставини справи та звичаї ділового обороту (п. 46 мотивів Директиви 2019/770, п. 24 мотивів Директиви 2019/771).

Новий критерій відповідності товару - зносостійкість (durability) міститься в Директиві 2019/771 та визначає раціональну необхідність функціональності товару протягом звичайного використання (ст. 7.1 (d), п. 32 мотивів Директиви 2019/771). Законодавче визначення цього поняття зумовлене сучасною концепцією кругової економіки й обгрунтованості довготривалого користування товаром. Зносостійкість товару як ознака його відповідності відома законодавству деяких держав-членів ЄС. Більше того, ідея цієї властивості товару була закладена у ст. 2 Директиви 1999/44/СС, але вона швидше охоплювала інші вимоги відповідності, такі як придатність за призначенням, висока якість і продуктивність ${ }^{28}$. Показник зносостійкості товару визначається не шляхом його екстремального використання ${ }^{29}$, а на підставі звичайного користування включно із необхідністю в обслуговуванні товару (п. 32 мотивів Директиви 2019/771).

Ще однією важливою новелою обох Директив, на якій варто, на нашу думку, зупинити увагу, є закріплення в європейському договірному праві обов'язку постачальника (продавця) інформувати споживача про оновлення цифрового контенту (товару із цифровими елементами) та можливість його здійснення 3 метою підтримання цих товарів чи цифрового контенту у відповідності протягом певного періоду часу. Зазначена вимога входить до критерію об’ єктивної відповідності (ч .2 ст. 8 Директиви 2019/770, ч. 3 ст. 7 Директиви 2019/771). Істотним є період, протягом якого такі оновлення повинні надаватися. У разі одноразового або кількох пов'язаних актів постачання (передання) цифрового контенту (товарів із цифровими елементами) постачальник (продавець) зобов'язаний оновлювати програмне забезпечення протягом періоду, на який споживач може обгрунтовано очікувати, враховуючи тип і призначення товару із цифровими елементами (цифрового контенту), обставини й особливості договору (п. ь ч. 2 ст. 8 Директиви 2019/770, п. а ч. 3 ст. 7 Директиви 2019/771). Оновлення цифро-

\footnotetext{
27 Staudenmayer D. The Directives on digital contracts: first steps towards the private law of the digital economy. European review of private law. 2020. Issue 2. Vol. 28. P. 239.

${ }^{28}$ Vanherpe J. White smoke, but smoke nonetheless: some (burning) questions regarding the Directives on sale of goods and supply of digital content. European review of private law. 2020. Vol. 28. Issue 2. P. 260.

${ }^{29}$ Staudenmayer D. The Directives on digital contracts: first steps towards the private law of the digital economy. European review of private law. 2020. Issue 2. Vol. 28. P. 239.
} 
вого контенту (цифрової послуги) повинно здійснюватися постачальником (продавцем) протягом усього передбаченого договором періоду постачання цифрового контенту (надання цифрової послуги) (п. а ч. 2 ст. 8 Директиви 2019/770, п. b ч. 3 ст. 7 Директиви 2019/771). Ані Директива 2019/770, ні Директива 2019/771 прямо не визначають обов'язок споживача здійснювати оновлення, проте, якщо останній не оновив програмне забезпечення, необхідне для підтримки відповідності цифрового контенту (товару із цифровими елементами), постачальник (продавець) звільняється від відповідальності за їхню невідповідність за умови попереднього повідомлення споживача про необхідність оновлення та наявність причинно-наслідкового зв'язку між відсутністю оновлення та невідповідністю (ч. 3 ст. 8 Директиви 2019/770, ч. 4 ст. 7 Директиви 2019/771).

За ч. 6 ст. 8 Директиви 2019/770 цифровий контент або цифрова послуга надаються в останній версії, доступній на момент укладення договору, якщо сторони не домовилися про інше (ч. 6 ст. 8). Директива 2019/771 не містить подібної норми ${ }^{30}$. Вважаємо цілком прийнятним застосування за аналогією наведеного положення Директиви 2019/770 до договірних правовідносин купівлі-продажу товарів із цифровими елементами. Проблематичнішою ж видається ситуація придбання за договором купівліпродажу товару без цифрових елементів. Виникає цілком логічне питання можливості застосування за аналогією наведеної норми і до такого виду відносин або необхідності закріплення аналогічного положення i в Директиві 2019/771.

На відміну від Директиви 1999/44/СС, нові Директиви містять положення про права третіх осіб (ст. 10 Директиви 2019/770 і ст. 9 Директиви 2019/771) i визначають механізми захисту прав у разі передання постачальником (продавцем) цифрового контенту (товару із цифровими елементами) в межах об'єктивних критеріїв відповідності, але порушуючи ліцензію у сфері авторського права (п. 54 мотивів Директиви 2019/770, п. 35 мотивів Директиви 2019/771). Наприклад, відсутність у споживача спроможності використовувати певні функції цифрового контенту або товарів і цифровими елементами, зумовленої реалізацією авторських прав автором ${ }^{31}$. Державичлени $\mathrm{CC}$ у наведеній ситуації мають можливість встановити правові наслідки недійсності такого договору або його розірвання.

\footnotetext{
30 Staudenmayer D. The Directives on digital contracts: first steps towards the private law of the digital economy. European review of private law. 2020. Issue 2. Vol. 28. P. 219-249.

Carvalho J.M. Sale of goods and supply of digital content and digital services - overview of Directives 2019/770 and 2019/771. EuCML. 2019. Heft 5. P. 199.

31 Staudenmayer D. The Directives on digital contracts: first steps towards the private law of the digital economy. European review of private law. 2020. Issue 2. Vol. 28. P. 242.
} 
У Директиві 2019/771 збільшено період дії презумпції невідповідності товару із шести місяців, як це попередньо визначалося положеннями Директиви 1999/44/СС, до одного року 3 моменту передання товару (ч. 1 ст. 11). Аналогічна норма закріплена i в ч. 2 ст. 12 Директиви 2019/770. Директива 2019/771 дозволяє збільшити цей період до двох років (ч. 2 ст. 11) і не знижувати значно наявний у державах-членах ЄC рівень захисту споживачів. Директива 2019/770 не передбачає такої можливості, тому період дії презумпції невідповідності цифрового контенту або цифрової послуги становить лише один рік. Споживач несе тягар доказування відсутності відповідності придбаного товару. Як вказував Суд Справедливості $\mathrm{CC}$ у справі $\mathrm{Faber}^{32}$, споживач повинен

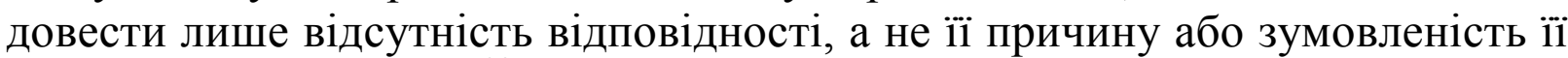
виникнення продавцем ${ }^{33}$.

Вперше на законодавчому рівні СС закріплено положення про тягар доведення невідповідності цифрового контенту або цифрової послуги, що залежить від особливостей виконання договірних зобов'язань. Він покладається на споживача, якщо договір виконується одним окремим актом або сукупністю індивідуальних актів постачання. У разі постійного постачання протягом певного періоду часу, вказаного у договорі, тягар доведення невідповідності покладається на продавця (ч. 3 ст. 12 Директиви 2019/770).

Таким чином, основними новелами законодавства СС у сфері відповідності товару $є$ поділ критеріїв відповідності на об'єктивний i суб'єктивний, закріплення поняття обгрунтованих очікувань як одного із вимог об'єктивної відповідності, вимоги зносостійкості товару, обов'язку постачальника (продавця) інформувати набувача про можливість оновлення цифрового контенту (товару із цифровими елементами) з метою їх підтримання у відповідності, правового недоліку товару як ознаки його невідповідності; особливостей тягаря доведення невідповідності цифрового контенту або цифрової послуги; збільшення періоду дії презумпції невідповідності.

\footnotetext{
${ }^{32}$ Judgment of the Court of Justice of the European Union C-497/13 Froukje Faber contra Autobedrijf Hazet Ochten BV. URL: http://curia.europa.eu/juris/liste.jsf?num=C-497/13 (дата звернення: 26.11.2020).

Podszun R. Procedural autonomy and effective consumer protection in sale of goods liability: easing the burden for consumers (even if they aren't consumers). EuCML. 2015. Heft 4. P. 152.

Rott P. Anmerkung zur Entscheidung des EuGH vom 04.06.2015, Az.: C-497/13 “Faber”. Europäische Zeitschrift für Wirtschaftsrecht. 2015. Heft 14. P. 561.

Patti F.P. The effectiveness of consumer protection in sales contracts - some observations from recent european case law. EuCML. 2015. Heft 5. P. 182.

${ }^{33}$ Patti F.P. The effectiveness of consumer protection in sales contracts - some observations from recent european case law. EuCML. 2015. Heft 5. P. 182; Staudenmayer D. The Directives on digital contracts: first steps towards the private law of the digital economy. European review of private law. 2020. Issue 2. Vol. 28. P. 247-248.
} 


\section{3. Сучасні виклики, пов'язані з відповідністю товарів}

Цифрова революція, поява нових технологій, «діджиталізація» та «стандартизація» договірних відносин створюють значні виклики для традиційних концепцій права ${ }^{34}$. Сучасний договір купівлі-продажу у багатьох випадках має ознаки тристоронніх відносин: споживач, продавець (виробник) i третя особа, що надає допоміжну цифрову послугу. К. Вендехорст влучно називає такі договори гібридними договорами купівлі-продажу ${ }^{35}$. Зазначене зумовлює питання можливості застосування положень Директиви 2019/770 і Директиви 2019/771 до правовідносин, у яких належному використанню придбаного товару перешкоджає недолік цифрової послуги, наданої третьою особою, а не продавцем товару.

Інший виклик пов'язаний із проблематикою встановлення невідповідності товару 3 урахуванням особливостей товарів із цифровим контентом i штучним інтелектом ${ }^{36}$, що потребують регулярних оновлень.

Актуальним $\epsilon$ питання відповідальності продавця у разі недоліку програмного забезпечення, підтримуючого функціонування товарів із цифровими елементами, придбаних споживачем (наприклад, фітнесбраслетів (fitness trackers), автомобілів (connected cars) із вбудованою системою навігації) та належної якості основного матеріального об'єкта. Потребує аналізу можливість охоплення поняттям невідповідності товару недоліку цифрової послуги (програмного забезпечення), яка підтримує функціональність смарт-пристрою ${ }^{37}$. Частково зазначене питання вирішено у ч. 3 ст. 3 Директиви 2019/771, котра поширює дію ії положень на товари із цифровими елементами, тобто будь-які матеріальні рухомі речі, які містять у собі або пов'язані із цифровим контентом (цифровою послугою) таким чином, що їх відсутність впливатиме на функціональність товару (п. b) ч. 5 ст. 2). Проте найскладніші із цих проблем зумовлені придбанням товарів із допоміжними цифровими послугами (наприклад, смарт-телевізорів, включаючи додатки Netflix i Youtube, розумних автомобілів із цифровими навігаційними системами, різдвяних вогників, що контролюються

\footnotetext{
${ }^{34}$ Savin A. Harmonising private law in cyberspace: the new directives in the digital single market context. Copenhagen business school law research paper. Series № 19-35. URL: https://ssrn.com/abstract=3474289 (дата звернення: 26.11.2020).

Schulze R. The new shape of European contract law. EuCML. 2015. Vol. 4. Issue 4. P. 139.

Twigg-Flesner Ch. From REFIT to a rethink: time for fundamental EU consumer law reform? EuCML. 2017. Heft 5. P. 189.

Luzak J. Digital age: time to say goodbye to traditional concepts. EuCML. 2018. Heft 4. P. 135.

${ }^{35}$ Wendehorst Ch. Hybride Produkte und hybrider Vertrieb. Sind die Richtlinienentwürfe vom 9. Dezember 2015 fit für den digitalen Binnenmarkt? / eds. by Wendehorst Ch., Zöchling-Jud B. Vienna, 2016. P. 45-89.

${ }^{36}$ Nemeth K., Carvalho J. M. Time for a change? Product liability in the digital era. EuCML. 2019. Heft 4. P. 161-162.

${ }^{37}$ Kalamees P., Sein K. Connected consumer goods: who is liable for defects in the ancillary digital service? EuCML. 2019. Heft 1. P. 13.
} 
додатками $)^{38}$. Споживач укладає із продавцем договір купівлі-продажу матеріального товару та додатковий ліцензійний договір із постачальником цифрового контенту на користування цифровими послугами. Зазначене породжує питання можливості споживача вимагати розірвання договору купівлі-продажу або зниження ціни на новий смарт-телевізор у разі проблеми з Netflix. Аналогічна ситуація виникає із неналежною роботою додатків смартфону, навігаційної системи розумного автомобіля.

Для товарів із цифровими елементами доволі складно визначити причину їх невідповідності та встановити момент іiі настання, що має важливе значення для переходу ризику невідповідності товару. Цікавою є ситуація неможливості синхронізації фітнес-трекера 3 відповідним додатком або розумного автомобіля з навігаційними картами через відсутність сумісності попередньо встановленого програмного забезпечення та його оновлення, якщо додаток повністю перестав працювати.

Оскільки продавець зазвичай не зобов'язаний за договором купівліпродажу надавати споживачеві цифрову послугу, яка підтримує функціонування товару, у доктрині висловлена пропозиція закріплення на законодавчому рівні гарантійного зобов'язання продавця забезпечити надання відповідних послуг споживачеві також після переходу ризику до покупця $^{39}$ або укладення додатково, окрім договору купівлі-продажу, договору про надання послуг між продавцем і покупцем (споживачем) ${ }^{40}$. Вважаємо, що продавець може нести відповідальність у разі несумісності товару із цифровими елементами 3 додатком, якщо він також $є$ виробником цієї програми. У наведеній ситуації доцільним є укладення додаткового до договору купівлі-продажу, договору про надання послуг ${ }^{41}$.

Закріплюючи критерій визначення відповідності товару, Директива 2019/771 використовує велику кількість оціночних понять, таких як «нормальний», «обгрунтований», «довговічний», «серйозний», «функціональний», «поінформований», відповідне тлумачення яких на практиці, на нашу думку, може бути суперечливим i зумовить значну кількість прецедентної практики Суду Справедливості ЄС.

\footnotetext{
${ }^{38}$ Sein K. Goods with digital elements and the interplay with Directive 2019/771 on the sale of goods. 2020. January 30. URL: http://dx.doi.org/10.2139/ssrn.3600137 (дата звернення: 26.11.2020).

39 Wendehorst Ch. Verbraucherrelevante Problemstellungen zu Besitz- und Eigentumsverhältnissen beim Internet der Dinge. SVRV. 2016. S. 121; Kalamees P., Sein K Connected consumer goods: who is liable for defects in the ancillary digital service? EuCML. 2019. Heft 1. P. 18-19.

40 Solmecke Ch., Vondrlik S.-E. Rechliche Probleme bei Produkten mit serverbasierten Zusatzdiensten. MultiMedia Recht. 2013. № 16. S. 755.

${ }^{41}$ Kalamees P., Sein K. Connected consumer goods: who is liable for defects in the ancillary digital service? EuCML. 2019. Heft 1. P. 20.
} 


\section{ВИСНОВКИ}

Європейське приватне право зазнає динамічних трансформацій, як і один із його основних інститутів - договірне право, ключова роль у якому відводиться нормам про купівлю-продаж. Нові законодавчі інструменти СС визначають інноваційні підходи до регулювання договірних відносин в епоху цифрової революції порівняно з національним законодавством або міжнародним уніфікованим правом.

3 позиції належного захисту прав покупця, котрому передано невідповідний договору товар, недостатньою $є$ реалізація загальних засад відповідальності за неналежне виконання зобов'язання, адже покупець, що на основі довіри до продавця оплачує товар, повинен отримати адекватне його очікуванням взаємне виконання. Виходячи із цього, цивільне право виробило особливу концепцію відповідальності продавця у разі продажу невідповідного товару, що вирізняється підставами відповідальності й обсягом правомочностей покупця порівняно із загальними засадами відповідальності за порушення зобов'язань. Основною підставою такої відповідальності $\epsilon$ невідповідність властивостей придбаного товару положенням договору й очікуванням покупця. Вперше концепція невідповідності проданого товару була закріплена у Конвенції ООН про договори міжнародної купівлі-продажу товарів 1980 р., а згодом у Директиві 1999/44/СС про деякі аспекти продажу споживчих товарів і пов'язаних із ними гарантій, Директиві 2019/770 про деякі аспекти договорів поставки цифрового контенту та цифрових послуг, Директиві 2019/771 про деякі аспекти договорів купівлі-продажу товарів.

Директиви 2019/770 та 2019/771 є головним викликом для споживчого права на європейському рівні. Незважаючи на те, що вони встановлюють максимальний рівень гармонізації, Директива 2019/771 надає державамчленам більше свободи порівняно із Директивою 2019/770. Однією із ключових новел європейського договірного права $\epsilon$ положення Директив, що визначають концепцію відповідності товару, цифрового контенту, цифрової послуги та містять суб'єктивні й об'єктивні критерії ії встановлення.

Закріплення в обох директивах багатьох оціночних понять неминуче призведе до великої кількості інтерпретаційних питань на практиці. Незважаючи на те, що Суд Справедливості СС компетентний у вирішенні таких питань, більш конкретні вказівки законодавця ЄС могли б підвищити юридичну визначеність у процесі реалізації цих норм. Ефективність на практиці нових законодавчих конструкцій продемонструє час. 


\section{АНОТАЦІЯ}

20 травня 2019 р. європейський законодавець прийняв нові законодавчі інструменти у сфері купівлі-продажу товарів i постачання цифрового контенту, які визначають вектор майбутнього розвитку договірного права Європейського Союзу. Директива 2019/770 про деякі аспекти договорів поставки цифрового контенту та цифрових послуг, Директива 2019/771 про деякі аспекти договорів купівлі-продажу товарів $\epsilon$ першими кроками адаптації європейського приватного права до вимог цифрової економіки. Нові законодавчі інструменти Свропейського Союзу приділяють значну увагу регулюванню питання відповідності товару. За умов інтеграції України до єдиного ринку Свропейського Союзу ключовим питанням виступає адаптація національного договірного права до законодавства Європейського Союзу, включаючи положення про відповідність товару. Автор простежує генезу становлення концепції відповідності товару, досліджує особливості законної та комерційної гарантії якості товару. Значна увага приділена розкриттю основних законодавчих новел у сфері договірних відносин купівлі-продажу товарів, зокрема відповідності товару та критеріїв іiі визначення; інформаційних зобов'язань продавця товару із цифровими елементами стосовно оновлення програмного забезпечення з метою підтримання їх у відповідності; презумпції невідповідності товару та тягаря іiі доведення; засобів правового захисту прав покупця, порушених у зв'язку з невідповідністю товару. Також розкривається проблема сучасних викликів, пов'язаних із відповідністю товарів, зокрема товарів із цифровим контентом і штучним інтелектом.

\section{ЛІТЕРАТУРА}

1. Bańczyk W. Zmiany przesłanek odpowiedzialności sprzedawcy w prawie polskim (od wady rzeczy sprzedanej do jej niezgodności z umową). Acta iuris stetinensis. 2018. № 3 (23). S. 7-34.

2. Byczkowska I. Odpowiedzialność z tytułu rękojmi za wady rzeczy sprzedanej (wybrane zagadnienia ). Państwo i prawo. 2000. Zeszyt 9 (655). S. 64-72.

3. Carvalho J.M. Sale of goods and supply of digital content and digital services overview of Directives 2019/770 and 2019/771. EuCML. 2019. Heft 5. P. 194-201.

4. Dajczak W. Znaczenie tradycji prawa rzymskiego dla europejskiej harmonizacji prawa prywatnego. Państwo i prawo. 2004. Zeszyt 2 (696). S. 57-68.

5. Ferrari F. The CISG and its impact on national legal systems. Sellier 2008. 489 p.

6. Frąckowiak J. Uprawnienia z rękojmi za wady fizyczne rzeczy sprzedanej. Przeglad prawa i administracji. 2004. T. LXIV. Rozprawy z prawa handlowego. S. 29-44. 
7. Gajek M. Niezgodność z umową jako przesłanka odpowiedzialności sprzedawcy towaru konsumpcyjnego. Monitor Prawniczy. 2003. № 5. S. 207-210.

8. Habryn-Motawska E. Niezgodność towaru konsumpcyjnego $\mathrm{z}$ umową sprzedaży konsumenckiej. Warszawa, 2010. $262 \mathrm{~s}$.

9. Jagielska M. Komentarz do art. 35 Konwencji ONZ. Konwencja wiedeńska o umowach międzynarodowej sprzedaży towarów. Komentarz / red. M. Pazdana. Kraków, 2001. $892 \mathrm{~s}$.

10. Judgment of the Court of Justice of the European Union C-497/13 Froukje Faber contra Autobedrijf Hazet Ochten BV. URL: http://curia.europa.eu/juris/ liste.jsf?num=C-497/13 (дата звернення: 26.11.2020).

11. Kalamees P., Sein K. Connected consumer goods: who is liable for defects in the ancillary digital service? EuCML. 2019. Heft 1. P. 13-22.

12. Katner W., Pisuliński J. Sprzedaż (w:) System prawa prywatnego. Prawo zobowiązań - część szczegółowa / red. J. Rajski. T. 7. Warszawa : C.H. Beck, 2018. $1312 \mathrm{~s}$.

13. Koch A. Wadliwość rzeczy sprzedanych w świetle Konwencji ONZ o międzynarodowej sprzedaży towarów. Przegląd Prawa Handlowego. 1998. № 10. S. 10-18.

14. Krupowicz M. Ocena kierunku zmian w zakresie ochrony konsumenta na gruncie ustawy z dnia 27 lipca 2002 r. o szczególnych warunkach sprzedaży konsumenckiej. Rejent. 2005. № 2. S. 136-148.

15. Łętowska E. Prawo umów konsumenckich. Warszawa, 2002. $630 \mathrm{~s}$.

16. Longchamps de Berier F. Skargi edylów kurulnych a dyrektywa 1999/44/EC Parlamentu Europejskiego i Rady w sprawie określonych aspektów sprzedaży i gwarancji na dobra konsumpcyjne. Studia Iuridica. 2005. T. XLIV. S. 427-437.

17. Loranc-Borkowska J. Rękojmia za wady przedmiotu zamówienia publicznego a gwarancja jakości. Prawo zamówień publicznych. 2014. № 1. S. $146-158$.

18. Lubełska-Sazanów M. Odpowiedziałsność z tytułu rękojmi za wady fizyczne przy sprzedaży zwierząt. Transformacje Prawa Prywatnego. 2015. № 4. S. 21-41.

19. Luzak J. Digital age: time to say goodbye to traditional concepts. EuCML. 2018. Heft 4. P. 133-135.

20. Makowska A. Sprzedaż konsumencka w prawie Unii Europejskiej i prawie polskim. Toruń, 2006. $106 \mathrm{~s}$.

21. Mokrysz-Olszyńska A. Dyrektywa 2011/83/UE z dnia 25 października 2011 w sprawie praw konsumentów jako kolejny etap na drodze tworzenia jednolitych reguł konkurencji na unijnym rynku. Internetowy kwartalnik antymonopolowy i regulacyjny. 2013. № 7 (2). S. 78-91. 
22. Nemeth K., Carvalho J.M. Time for a change? Product liability in the digital era. EuCML. 2019. Heft 4. P. 160-161.

23. Patti F.P. The effectiveness of consumer protection in sales contracts - some observations from recent european case law. EuCML. 2015. Heft 5. P. 179-184.

24. Podrecka M. Rękojmia za wady prawne rzeczy sprzedanej. Warszawa, 2011. $584 \mathrm{~s}$.

25. Podrecki P., Zoll F. Odpowiedzialność z tytułu rękojmi i gwarancji w umowach sprzedaży z udziałem konsumentów. Ochrona konsumentów / red. E. Traple, M. du Vall. Cz. 1. Warszawa 1998. S. 107-125.

26. Podszun R. Procedural autonomy and effective consumer protection in sale of goods liability: easing the burden for consumers (even if they aren't consumers). EuCML. 2015. Heft 4. P. 149-153.

27. Popiołek W. Obowiązki sprzedającego. Komentarz do art. 30. Konwencja wiedeńska o umowach międzynarodowej sprzedaży towarów. Komentarz / red. M. Pazdana. Kraków, 2001. 892 s.

28. Rembieliński A. Rękojmia sprzedawcy za wady fizyczne rzeczy. Ogólne warunki umów sprzedaży i dostawy. Komentarz / A. Rembieliński, J. Koprowski, A. Jaźwiński. Warszawa, 1979. 350 s.

29. Rott P. Anmerkung zur Entscheidung des EuGH vom 04.06.2015, Az.: C-497/13 "Faber". Europäische Zeitschrift für Wirtschaftsrecht. 2015. Heft 14. P. 556-562.

30. Savin A. Harmonising private law in cyberspace: the new directives in the digital single market context. Copenhagen business school law research paper. Series. № 19-35. URL: https://ssrn.com/abstract=3474289 (дата звернення: 26.11.2020).

31. Schulze R. Supply of digital content - a new challenge for european contract law. European contract law and the digital single market - the implications of the digital revolution / ed by Franceschi A.D. Intersentia 2016. P. 127-144.

32. Schulze R. The new shape of European contract law. EuCML. 2015. Vol. 4. Issue 4. P. 139-144.

33. Sikorska A. Ciężar dowodu w przypadku odstąpienia od umowy sprzedaży przez kupującego z powodu wad rzeczy lub niezgodności towaru z umową. Radca prawny. 2005. № 1. S. 60-66.

34. Solmecke Ch., Vondrlik S.-E. Rechliche Probleme bei Produkten mit serverbasierten Zusatzdiensten. MultiMedia Recht. 2013. № 16. S. 755-760.

35. Staudenmayer D. The Directives on digital contracts: first steps towards the private law of the digital economy. European review of private law. 2020. Issue 2. Vol. 28. P. 219-249.

36. Strugała R. Odpowiedzialność odszkodowawcza sprzedawcy związana $\mathrm{z}$ realizacją uprawnień $\mathrm{z}$ tytułu rękojmi a ogólne zasady kontraktowej 
odpowiedzialności odszkodowawczej. Transformacje Prawa Prywatnego. 2015. № 4. P. 93-109.

37. Szczotka J. Sprzedaż konsumencka. Komentarz. Lublin 2007. $206 \mathrm{s.}$

38. Szpunar A. Uwagi w sprawie wykładni art. 568 k.c. Przegląd prawa handlowego. 1997. № 5. S. 1-6.

39. Twigg-Flesner Ch. From REFIT to a rethink: time for fundamental EU consumer law reform? EuCML. 2017. Heft 5. P. 185-189.

40. Vanherpe J. White smoke, but smoke nonetheless: some (burning) questions regarding the Directives on sale of goods and supply of digital content. European review of private law. 2020. Vol. 28. Issue 2. P. 251-273.

41. Wendehorst Ch. Verbraucherrelevante Problemstellungen zu Besitz- und Eigentumsverhältnissen beim Internet der Dinge. SVRV. 2016. $125 \mathrm{~s}$.

42. Wendehorst Ch. Hybride Produkte und hybrider Vertrieb. Sind die Richtlinienentwürfe vom 9. Dezember 2015 fit für den digitalen Binnenmarkt? / eds. by Wendehorst Ch., Zöchling-Jud B. Vienna, 2016. P. 45-89.

43. Widło J. Rękojmia za wady fizyczne w świetle nowelizacji Kodeksu cywilnego. Monitor Prawniczy. 2015. № 4. S. 177-186.

44. Zimmermann R. The law of obligations. Roman foundations of the civilian tradition. Oxford, 1996. $1241 \mathrm{p}$.

45. Zoll F. Problem negatywnego uzgodnienia cech rzeczy sprzedanej w oczekiwaniu na wspólne europejskie prawo sprzedaży. Transformacje prawa prywatnego. 2012. № 2. S. 167-174.

46. Żuławska C. Uwagi o „europeizacji” prawa umów. Kwartalnik Prawa Prywatnego. 2001. № 2. S. 229-239.

47. Żuławska C. Zabezpieczenie jakości świadczenia. Studia cywilistyczne. 1978. T. 29. S. 5-92.

Information about author: Savanets L. M.,

Candidate of Law, Associate Professor, Associate Professor at the Department of International Law and Migration Policy West Ukrainian National University 11, Lvivska str., Ternopil, 46000, Ukraine 